\title{
PERLINDUNGAN HUKUM TERHADAP KESELAMATAN PENUMPANG KAPAL LAUT BERDASARKAN UNDANG-UNDANG NOMOR 17 TAHUN 2008 TENTANG PELAYARAN DI INDONESIA
}

\author{
Nur Paikah \\ Prodi HTN, Sekolah Tinggi Agama Islam Negeri (STAIN) Watampone \\ Email : Nurpaikah78@gmail.com
}

\begin{abstract}
Abstrak
Transportasi laut memegang peranan yang sangat penting untuk memudahkan pengangkutan orang dan barang. Disamping itu, transportasi juga berperan sebagai penunjang, pendorong dan penggerak bagi pertumbuhan daerah yang memiliki sumber daya alam yang besar. Mengingat pentingnya angkutan laut maka perlunya hukum untuk mengatur sistem keselamatan pengangkutan laut yang diatur dalam Undang-Undang Nomor 17 Tahun 2008 tentang Pelayaran. Dalam hal keselamatan pelayaran harus menjadi perhatian oleh perusahaan yang bergerak di bidang pelayaran hal ini ditegaskan dalam Pasal 40 ayat (1) yang intinya menegaskan bahwa perusahaan angkutan di perairan bertanggungjawab terhadap keselamatan dan keamanan penumpang dan/atau barang yang diangkutnya.Walaupun terkadang pengangkutan dengan menggunakan kapal laut seringkali menimbulkan suatu permasalahan bagi pelayaran penumpang. Salah satunya adalah tidak terpenuhinya persyaratan teknis kelaiklautan dan persyaratan pelayanan minimal angkutan penyeberangan. Sehingga tidak sedikit penumpang mengalami kerugian baik materil maupun non materil.Berdasarkan realitas tersebut menunjukan perlindungan keselamatan penumpang harus mendapat jaminan keselamatan dan keamanan berdasarkan UndangUndang Nomor 17 Tahun 2008 Tentang Pelayaran yang dengan jelas menyebutkan bahwa penumpang berhak mendapat perlindungan untuk keselamatannya.
\end{abstract}

Kata Kunci : Pelindungan Hukum, Penumpang Kapal Laut, Perairan Indonesia

\section{A. Latar Belakang Masalah}

\section{Pendahuluan}

Indonesia adalah negara kepulauan berciri nusantara yang disatukan oleh wilayah perairan dan udara dengan batas-batas hak-hak dan kedaulatan yang ditetapkan oleh undang-undang. Dalam upaya mencapai tujuan nasional berdasarkan pancasila dan 
Undang-Undang Dasar 1945, mewujudkan wawasan nusantara serta memantapkan ketahanan nasional diperlukan sistem transportasi nasional yang efektif dan efisien, menunjang serta menggerakkan dinamika pembangunan dan mendukung pengembangan wilayah serta lebih memantapkan perkembangan kehidupan bermasyarakat, berbangsa dan bernegara, turut mendukung pertahanan dan keamanan, serta meningkatkan hubungan internasional. ${ }^{1}$

Menyadari pentingnya peran transportasi, angkutan laut sebagai sebagai salah satu roda penggerak perekonomian bangsa, transportasi harus ditata dalam suatu kesatuan sistem transportasi nasional yang terpadu dan mampu mewujudkan penyediaan jasa transportasi yang seimbang atau sesuai dengan tingkat kebutuhan dan tersedianya pelayanan angkutan yang baik, mudah dicapai dengan kebutuhan penumpang. ${ }^{2}$

Angkutan laut yang mempunyai karakteristik pengangkutan secara nasional dan menjangkau seluruh wilayah melalui perairan perlu dikembangkan potensinya sebagai penghubung antar wilayah, baik nasional maupun internasional termasuk lintas batas, karena digunakan sebagai sarana untuk menunjang, mendorong dan menggerakkan pembangunan nasional dalam upaya meningkatkan kesejahteraan rakyat serta menjadi perekat negara kesatuan Republik Indonesia. ${ }^{3}$ Mengingat pentingnya angkutan laut, maka diperlukan hukum untuk mengatur sistem keselamatan pengangkutan laut. Saat ini, pengangkutan laut diatur dalam Undang-Undang Nomor 17 Tahun 2008 Tentang Pelayaran. Dalam hal keselamatan penumpang diatur dalam Pasal 40 ayat (1) yang menyebutkan bahwa perusahaan angkutan di perairan bertanggungjawab terhadap keselamatan dan keamanan penumpang. ${ }^{4}$

\footnotetext{
${ }^{1}$ R. Wiryono Prodjodikoro, Hukum Laut Bagi Indonesia, Sumur, Bandung, 1981, hlm. 13

2 Abdul Kadir Muhammad, Hukum Pengangkutan Darat, Laut dan Udara, PT. Citra Aditya, Bandung, 1991, hlm 7

${ }^{3}$ Rediks Purba, Angkutan Muatan Laut, Bharata Karya Aksara, Jakarta, 1990, hlm 14

${ }^{4}$ Undang-Undang Nomor 17 Tahun 2008 Tentang Pelayaran
} 
Berdasarkan uraian tersebut, sangat jelas bahwa pengangkutan laut, penumpang berhak mendapatkan perlindungan hukum dari perusahaan pengangkutan. Apalagi saat ini, transportasi angkutan laut masih tetap menjadi pilihan sebagian masyarakat selain menggunakan transportasi darat dan udara. Penggunaan perjalanan melalui kapal laut oleh masyarakat sangat efektif untuk mengantarkan penumpang sampai ke daerah tempat tujuan akhir. Kendati demikian, terkadang pengangkutan kapal laut seringkali menimbulkkan suatu permasalahan, diantaranya masih terdapat banyak pelanggaran terhadap ketentuan dalam Pasal 61 ayat (3) Peraturan Pemerintah Nomor 20 Tahun 2010 Tentang Angkutan Perairan yang mewajibkan setiap kapal yang melayani angkutan penyeberangan wajib memenuhi persyaratan : 5

1. Persyaratan teknis kelaiklautan dan persyaratan pelayanan minimal angkutan penyeberangan;

2. Memiliki spesifikasi teknis sesuai dengan fasilitas pelabuhan yang digunakan untuk melayani angkutan penyeberangan atau terminal penyeberangan pada lintas yang dilayani.

3. Memiliki dan/atau mempekerjakan awak kapal yang memenuhi persyaratan kualifikasi yang diperlukan oleh kapal penyeberangan

4. Memiliki fasilitas bagi kebutuhan awak kapal maupun penumpang kendaraan beserta muatannya

5. Mencantumkan identitas perusahaan dan nama kapal

6. Mencantumkan informasi atau petunjuk yang diperlukan dengan menggunakan bahasa Indonesia dan bahasa Inggris.

Pelanggaran terhadap ketentuan di atas timbul sebagai akibat dari kelalaian penumpang itu sendiri, juga dapat disebabkan oleh kelalaian pengangkutan di pelabuhan persinggahan pengangkutan penumpang. Sehingga tidak sedikit mengalami kerugian baik

\footnotetext{
${ }^{5}$ Pasal 6 ayat (1) Peraturan Pemerintah Nomor 20 Tahun 2010 Tentang Angkutan Perairan
} 
materil maupun non materil diakibatkan pelayanan pengangkutan yang tidak baik. Seperti tenggelamnya KMP Wimala Dharma di perairan selat laut Lombok pada tahun 2003 yang menimbulkan korban jiwa sebanyak 5 orang. Pada 22 November 2009, giliran KM Dumai Ekspres 10 yang tenggelam di perairan Tekong Hiu Kecil Tanjung Sekoci Kepulauan Riau. Dalam tragedi ini, setidaknya dilaporkan sebanyak 42 orang ditemukan meninggal dan 32 orang dinyatakan hilang. Kejadian memilukan tersebut diakibatkan persoalan kelebihan muatan dan faktor abai terhadap peringatan cuaca. ${ }^{6}$

Selain itu, kasus terbaru adalah tragedi tenggelamnya KM Lestari Maju di perairan Selayar Sulawesi Selatan yang tenggelam pada tanggal 3 Juli 2018 sekitar pukul 10.00 Wita, akibat lambung kapal bocor, berangkat dari pelabuhan Bira Bulukumba tujuan pelabuhan Pamatata, Selayar Sulawesi Selatan. ${ }^{7}$ penumpang berjumlah 139 orang, 2 unit bus, 18 unit sepeda motor, 14 mini bus dan 14 unit truk. Menegaskan peristiwa tersebut, sebanyak 87 orang yang terluka dan butuh perawatan, 25 orang meninggal dunia dan selebihnya belum ditemukan. Kapal Motor (KM) Lestari Maju adalah kapal pengangkutan barang yang statusnya ditarik karena tidak layak untuk beroperasi. Namun, pemerintah setempat menerbitkan Surat Layak Operasi sekaligus mendapat izin untuk beroperasi sebagai kapal pengangkutan reguler Bira-Pamatata. Meskipun kondisi kapal sering dikeluhkan oleh warga setempat dengan alasan kapal sudah tua, sudah banyak perbaikan dan dianggap tidak layak. ${ }^{8}$

Kejadian memilukan tersebut terjadi dengan persoalan dugaan kelebihan muatan, faktor abai terhadap syarat-syarat yang telah ditentukan dalam Undang-Undang Nomor 17 Tahun 2008 Tentang Pelayaran Jo Peraturan Pemerintah Nomor 20 Tahun 2010

${ }^{6}$ Aswab Nanda $\quad$ Pratama, $15 \quad$ Pristiwa $\quad$ Kapal
https://nasional.kompas.com/read/2018/06/23/15220601/15-peristiwa-kapal-tenggelam-dari-2003-hingga-
2018?page=all
${ }^{7}$ Fajar, edisi Rabu 4 Juli 2018
${ }^{8}$ ibid


Tentang Angkutan Perairan serta kapal tersebut ditujukan untuk mengangkut barang bukan diperuntukan untuk penumpang.

Berdasarkan realitas tersebut telah menunjukkan bahwa perlindungan keselamatan penumpang yang menjadi kewenangan perusahaan pengangkutan laut tidak berjalan dengan efisien walaupun Undang-Undang Nomor 17 Tahun 2008 Tentang Pelayaran telah menyebutkan dengan jelas bahwa penumpang berhak mendapat perlindungan untuk keselamatannya, sekaligus memperlihatkan jaminan keselamatan dan keamanan penumpang masih sangat lema yang tentu saja memerlukan perhatian serius semua pihak agar tidak merugikan kepentingan penumpang yang menggunakan transportasi laut.

\section{B. Rumusan Masalah}

Berdasarkan latar belakang masalah sebagaimana yang telah diuraikan di atas maka permasalahan dapat dirumuskan sebagai berikut : Bagaimana perlindungan hukum terhadap penumpang kapal laut berdasarkan Undang-Undang Nomor 17 Tahun 2008 Tentang Pelayaran di Indonesia ? serta bagaimana upaya yang ditempuh dalam memaksimalkan perlindungan hukum terhadap penumpang kapal laut berdasarkan Undang-Undang Nomor 17 Tahun 2008 Tentang Pelayaran?

\section{Pembahasan}

\section{Perlindungan Hukum terhadap Penunpang Kapal Laut Berdasarkan Undang- Undang Nomor 17 Tahun 2008 Tentang Pelayaran di Indonesia}

Sebagai negara kepulauan transportasi laut menjadi vital dan strategis untuk menghubungkan satu pulau ke pulau lainnya. Transportasi laut sebagai salah satu unsur transportasi yang ada di Indonesia dilihat dari segi geografis peranannya sangat besar. Hal ini disebabkan transportasi laut merupakan sarana yang sangat penting dalam 
memperlancar roda perekonomian, memperkokoh persatuan serta mempengaruhi semua aspek kehidupan bangsa dan negara.

Sebagai sarana utama yang banyak digunakan masyarakat, pengangkutan melalui transportasi laut terus mengalami perkembangan. Salah satu alasannya adalah biaya transportasi laut cukup terjangkau oleh masyarakat, akses mendapatkan tiket dengan mudah, maka wajar jika tiap tahunnya animo masyarakat menggunakan transportasi laut terus mengalami peningkatan dari tahun ke tahun. Dengan kondisi penumpang yang terus mengalami peningkatan, maka PT ASDP sebagai perusahaan nasional dan Pihak Pengelola Pelabuhan (UPP) dalam menyelenggarakan pengangkutan harus benar-benar memberikan perlindungan hukum sebagaimana yang ditegaskan dalam Undang-Undang Nomnor 17 Tahun 2008 Tentang Pelayaran Jo Peraturan Pemerintah Nomor 20 Tahun 2010 Tentang Angkutan Perairan.

Perlindungan hukum merupakan identik dengan jaminan hak dan kewajiban dalam suatu perjanjian antara kedua belah pihak. ${ }^{9}$ Perlindungan hukum digunakan dalam upaya melindungi kepentingan pihak-pihak dalam suatu perjanjian yang sah secara hukum. Adapun bentuk perlindungan hukum terhadap penumpang angkutan laut dibagi atas dua yaitu perlindungan hukum preventif dan perlindungan hukum represif. ${ }^{10}$

Perlindungan hukum preventif merupakan tindakan yang dilakukan oleh pihak pengangkutan laut sebelum penyimpangan sosial terjadi agar suatu tindak pelanggaran dapat diredam atau dicegah, misalnya sosialisasi dalam bentuk pengarahan kepada penumpang agar membeli tiket pada tempat yang disediakan tidak melalui calo karena bersifat ilegal. Selain itu, memberikan bimbingan kepada penumpang dalam hal mendapatkan keselamatan sebelum kapal diberangkatkan, diantaranya arahan dalam

${ }^{9}$ Wibowo Soedjono, Hukum Perkapalan dan PengangkutaLaut, Rina Aksara, Jakarta, 1993, hlm 42

${ }^{10}$ Wibowo Soedjono, Sarana-sarana Penunjang Pengangkutan Laut, Bina Aksara, jakarta, 1983, hlm. 
penggunaan pelambung dan sekoci agar dapat digunakan sebagaimana mestinya jika terjadi hal-hal yang tidak diinginkan pada saat melakukan perjalanan laut. ${ }^{11}$ Namun, realitasnya masih ditemukan petugas sendiri yang bertindak selaku calo dan bahkan sering terjadi kerjasama yang saling menguntungkan antara calo dan petugas. Perlindungan hukum represif adalah suatu tindakan aktif yang dapat dilakukan oleh pihak pengangkutan laut pada saat penyimpangan sosial terjadi, agar penyimpangan yang sedang terjadi dapat dihentikan, yang meliputi tanggung jawab atas keselamatan penumpang sebagai obyek dalam perjalanan laut. ${ }^{12}$ Hal yang paling utama yang harus diperhatikan pada pengangkut angkutan laut yang diberikan sejak naik di atas kapal sampai penumpang turun di tempat tujuan. Sistem tersebut dirancang untuk menjamin terselenggaranya perlindungan yang efektif dari kemungkinan risiko dan bahaya yang dapat diperkirakan dan diantisipasi sebagai penyebab korban luka, kematian, gangguan kesehatan, harta benda dan pengrusakan lingkungan yang tidak seharusnya terjadi. Bentuk perlindungan hukum represif belum berjalan secara maksimal terutama masih didapatkan sekoci, baju pelampung dan alat penolong lainnya kurang berfungsi sebagaimana mestinya serta kurangnya kebersihan dalam kapal sehingga penumpang merasa tidak nyaman.

Bentuk perlindungan hukum represif lainnya adalah memberikan jaminan keselamatan penumpang dalam bentuk asuransi yang sudah diperjanjikan sebelumnya dalam hal terjadi suatu transaksi antara penumpang dan jasa pengangkutan yang dituangkan dalam bentuk perikatan. Melalui program asuransi, maka ada jaminan keselamatan penumpang berupa ganti kerugian apabila dikemudian hari terjadi hal-hal yang tidak diinginkan. Selain itu, perlindungan hukum berkaitan dengan jaminan ganti kerugian bagi penumpang yang mengalami hal-hal yang tidak diinginkan seperti mengalami kerugian. Apabila tidak menemukan titik temu perihal jaminan keselamatan dan ganti kerugian, maka

\footnotetext{
${ }^{11}$ Ibid, hlm 11

12 Wibowo Soedjono, Hukum Pnegangkutan Laut di Indonesia dan Perkembangannya, Liberty, Yogyakarta, 199, hlm 12.
} 
penumpang dapat menempuh jalur hukum, apabila pihak perusahan pengangkutan laut tidak menghiraukan keluhan yang dialami penumpang. Upaya hukum yang ditempuh bisa melalui pengadilan (litigasi) atau diluar pengadilan (non litigasi) atas kesepakatan bersama mereka, misalnya konsiliasi, mediasi, negosiasi dan arbitrase. ${ }^{13}$

Banyaknya masalah-masalah yang terjadi di masyarakat dalam hal pengangkutan laut, diantaranya yang sering dikeluhkan oleh penumpang kapal laut adalah :

1. Ruang tunggu penumpang masih dirasa tidak nyaman dengan alasan penumpang menunggu keberangkatan terlalu lama sehingga penumpang bedesak-desakan di ruang tunggu.

2. Kebersihan dalam kapal tekadang tidak diperhatikan oleh pihak pemilik kapal

3. Masih adanya preman di ruang tunggu, sehingga mengganggu kenyamanan penumpang

4. Terkadang penumnpang tidak memperoleh tempat duduk sehingga harus melantai dan asap rook masih dirasakan dimana-mana

5. Masih banyaknya pedagang asongan dan calo.

6. Penumpang masih merasa tidak aman apabila banyak orang tidak berkepentingan di atas kapal

7. Penumpang mengeluhkan masih adanya kehilangan barang di atas kapal

8. Terkadang jadwal keberangkatan tidak tepat waktu sehingga penumpang harus menunggu lama. ${ }^{14}$

Dari beberapa permasalahan di atas, maka harus benar-benar mendapatkan suatu jaminan perlindungan hukum. Melalui perlindungan hukum represif dan preventif maka permasalahan di atas dapat diatasi, untuk itu sangat penting dilakukan oleh perusahaan pengangkutan laut mengimplementasikan amanat Undang-Undang Nomor 17 Tahun 2008

\footnotetext{
${ }^{13}$ M. Husyen, Umar, Menuju Hukum Angkutan Laut Nasional, BPHN, Jakarta, 1999, hlm 15 ${ }^{14}$ Ibid, hal 22
} 
Tentang Pelayaran Jo Peraturan Pemerintah Nomor 20 Tahun 2010 Tentang Angkutan Perairan.

\section{Upaya yang ditempuh dalam memaksimalkan perlindungan hukum terhadap penumpang kapal laut berdasarkan Undang-Undang Nomor 17 Tahun 2008 Tentang Pelayaran di Indonesia.}

Penumpang merupakan salah satu unsur yang paling penting dalam sebuah pengangkutan baik pengangkutan darat, laut maupun udara. Meskipun terkadang paling rentan mengalami perlakuan yang kurang menyenangkan. Untuk itu, perlunya jaminan perlindungan hukum bagi penumpang, khsusnya penumpang angkutan laut.

Adapun upaya yang bisa dilakukan dalam memaksimalkan perlindungan hukum terhadap penumnpang adalah memperbaiki sistem hukum dalam bidang pelayaran diantaranya subtansi ketentuan mengenai pelayaran lebih ditingkatkan bentuk sanksinya kepada perusahaan, terutama pada bidang perlindungan hukum terhadap kerugian yang diderita oleh penumpang, terkadang pihak perusahaan pengangkutan kurang perhatian pada penumpang yang mengalami kerugian.

Apalagi saat ini, animo masyarakat untuk perjalanan laut masih tinggi, maka tentu saja risiko pun siap ditanggung oleh penumpang. Tidak ada penumpang yang menginginkan sebuah musibah pada transportasi laut, udara maupun transportasi darat. Tapi terlepas dari itu, ada juga penumpang yang mengalami kerugian dan memiliki kendala saat menuntut haknya sebagai penumpang.

Selain itu, upaya lain yang ditempuh adalah penyediaan sarana dan prasarana yang layak dan nyaman bagi penumpang, diantaranya penyediaan fasilitis ruang tunggu yang luas, tersedianya kantor-kantor cabang dimana-mana bagi perusahaan pengangkutan terutama memudahkan bagi penumpang kapal laut apabila akan melakukan pengaduan atau 
permohonan tuntutan ganti rugi apabila terjadi penyalahgunaan wewenang oleh perusahaan pengangkutan.

Selain itu, yang terpenting adalah perbaikan kultur (budaya hukum) baik penumpang maupun perusahaan pengangkutan dengan membudayakan slogan kepuasan penumpang harus selalu diperhatikan, sehingga penumpang merasa nyaman dan aman dalam menggunakan jasa penrusahaan pengangkutan tersebut. Selain itu tidak ada beban psikologis bagi penumpang yang mengalami masalah dalam perjalanan karena para kru dan petugas siap memberi informasi atau penjelasan kepada penumpang sebagaimana yang ditegaskan dalam pasal 60 ayat (1) Undang-Undang Nomnor 17 Tahun 2008 Tentang Pelayaran.

\section{Penutup}

Berdasarkan uraian yang telah dikemukakan pada bagian terdahulu maka kesimpulan yang dapat diambil adalah bahwa, perlindungan hukum terhadap penumpang kapal laut berdasarkan Undang-Undang Nomor 17 Tahun 2008 Tentang Pelayaran adalah menjadi hak penumpang, dan perusahaan pengangkutaan berkewajiban untuk memberikan perlindungan hukum terhadap penumpang.

Adapun bentuk-bentuk perlindungan hukum terhadap penumpang adalah pelrindungan hukum preventif meliputi sosialisasi dan bimbingan kepada penumpang kapal laut baik sebelum naik kapal dan sampai ke tujuan. Perlindungan hukum represif meliputi jaminan keselamatan penumpang, pemberian ganti kerugian yang layak kepada penumpang yang mengalami kerugian ataupun kecelakaan serta proses hukum yang dilakukan penumpang untuk mendapatkan suatu bentuk perlindungan melalui pengaduan ke pihak PT ASDP dan melaporkan kepada pihak yang berwajib apabila penumpang tidak mendapatkan bentuk perlindungan hukum baik perlindungan hukum preventif maupun represif. 
Upaya yang ditempuh dalam memaksimalkan pelindungan hukum terhadap penumpang kapal laut adalah perlunya ketegasan dari pemerintah dalam memberi sanksi kepada perusahaan pengangkutan agar lebih serius dan memnperhatikan hak-hak penumpang terutama dalam hal pelindungan jaminan ganti rugi yang layak, aksebilitas dalam mengajukan klaim dan tuntutan dengan kemudahan melaporkan pengaduan yang diajukan di kantor-kantor cabang yang tersedia. Serta yang lebih terpenting adalah pelayanan yang baik dan menyenangkan dengan berdasar pada prinsip memprioritaskan kepuasaan dan kenyamanan penumpang.

\section{DAFTAR PUSTAKA}

\section{Buku}

Abdul Kadir Muhammad, 1991, Hukum Pengangkutan Darat, Laut dan Udara, PT. Citra Aditya, Bandung

M. Husyen, Umar, 1999, Menuju Hukum Angkutan Laut Nasional, BPHN, Jakarta

Rediks Purba, 1990, Angkutan Muatan Laut, Bharata Karya Aksara, Jakarta

R. Wiryono Prodjodikoro, 1981, Hukum Laut Bagi Indonesia, Sumur, Bandung

Tuti Triyanti Gondokusumo, 1985, Pengangkutan Melalui Laut, Fakultas Hukum Undip, Semarang

Wibowo Soedjono, 1993, Hukum Perkapalan dan PengangkutaLaut, Rina Aksara, Jakarta

---------, 1983, Sarana-sarana Penunjang Pengangkutan Laut, Bina Aksara, Jakarta

Perkembangannya, Liberty, Yogyakarta
--------1907 Lautan

Internet

Aswab Nanda Pratama, 15 Pristiwa Kapal Tenggelam 2003-2008, https://nasional.kompas.com/read/2018/06/23/15220601/15-peristiwa-kapaltenggelam-dari-2003-hingga-2018?page=all

Peraturan Perundang-undangan

Undang-Undang Nomor 17 Tahun 2008 Tentang Pelayaran (Lembaran Negara Republik Indonesia Tahun 2008 Nomor 64, Tambahan Lembaran Negara Republik Indonesia Nomor 4849)

Peraturan Pemerintah Nomor 20 Tahun 2010 Tentang Angkutan Di Perairan (Lembaran Negara Republik Indonesia Tahun 2010 Nomor 26, Tambahan Lembaran Negara Republik Indonesia Nomor 5108) 